\title{
Management of jejunal diverticulitis. Experience in our center
} Manejo de la diverticulitis yeyunal. Experiencia en nuestro centro

Javier Serrano-González*, Mariano Artés-Caselles, Laura Román-García de León, Pau Plá-Sánchez and Víctor Sánchez-Turrión

Department of General Surgery and Digestive System, Hospital Universitario Puerta de Hierro Majadahonda, Majadahonda, Madrid, Spain

\begin{abstract}
Jejunal diverticular disease is a very uncommon pathology often asymptomatic. Associated complications appear in less than $30 \%$ of patients and they can present as diverticulitis, refractary inflammation, obstruction, hemorrhage, perforation or intraabdominal abscess formation. Clinical manifestations are usually unspecific and high suspicion index is required to reach the diagnosis. Treatment of complications includes volume replacement, transfusions, antibiotic therapy, percutaneous drainage or surgical intervention. We present a retrospective observational study of the cases treated in our hospital between 2007 and 2016.
\end{abstract}

KEY WORDS: Jejunal. Diverticulosis. Diverticulitis. Intestinal perforation. Intestinal resection.

\section{Resumen}

La enfermedad diverticular yeyunal es una condición clínica muy poco frecuente y habitualmente asintomática. Las complicaciones asociadas aparecen en menos del $30 \%$ de los pacientes y pueden manifestarse como inflamación de los divertículos, obstrucción intestinal, hemorragia digestiva, malabsorción intestinal, formación de abscesos intraabdominales y perforación. La clínica de los pacientes es muchas veces inespecífica, requiriendo un alto grado de sospecha para llegar al diagnóstico. El tratamiento de las complicaciones de la enfermedad diverticular es variado, incluyendo reposición de volumen o transfusiones, antibioticoterapia, drenaje percutáneo o intervención quirúrgica. Presentamos un estudio observacional retrospectivo de los casos tratados en nuestro hospital entre 2007 y 2016.

PALABRAS CLAVE: Yeyuno. Diverticulosis. Diverticulitis. Perforación intestinal. Resección intestinal.

\section{Correspondence:}

*Javier Serrano-González

Manuel de Falla, 1

28222 Majadahonda (Madrid), España

E-mail: javierserranogdr@gmail.com
Date of reception: 18-12-2017

Date of acceptance: 11-04-2018

DOI:10.24875/CIRUE.M18000021
Cir Cir. 2018;86:130-133

Contents available at PubMed www.cirugiaycirujanos.com 


\section{Introduction}

Diverticula are saccular formations arising from the intestinal wall. They are much more frequent in the colon, although they can also be found in the small intestine. Of those appearing in the small intestine, duodenal diverticula have a higher prevalence $(80 \%)$ than those located in the jejunum and ileum $(20 \%)^{1}$. Depending on the layers of the wall that are affected, they can be classified as true diverticula (involving the entire intestinal wall) and pseudodiverticula (where the mucosa and submucosa are herniated through the muscular layer, usually in areas of wall weakness, coinciding with the passage of nutritional vessels along the mesentery $)^{2,3}$, with the latter being more common. They can also be divided into intraluminal (congenital) or extraluminal (usually acquired).

Jejunal diverticular disease is a rare clinical condition. Most patients do not suffer any symptoms associated with this disease if there are no complications, which only appear in $10-30 \%$ of cases. These complications include inflammation of diverticula (diverticulitis), intestinal obstruction due to volvulus, bleeding, intestinal malabsorption, intra-abdominal abscesses formation and abdominal cavity free perforation ${ }^{4-6}$. In these cases, clinical presentation is often nonspecific, and a high degree of suspicion is therefore required for their diagnosis.

Diagnosis is, in most cases, casual, during a complementary test for another reason.

Treatment of asymptomatic diverticula is not indicated, and only complications are managed in case they occur?.

\section{Methods}

We present the results of a descriptive, retrospective, observational study conducted in our hospital, a tertiary care center, of patients diagnosed with jejunal diverticulitis between 2007 and 2016. All patients were diagnosed by abdominal computed tomography (CT). In total, 12 cases were analyzed. The collected data included age at presentation of the condition, gender, risk factors for poor evolution, presence of data consistent with complications, administered treatment and subsequent evolution of each patient.

\section{Results}

Twelve patients were analyzed, out of which 7 were men $(58 \%)$ and 5 women (42\%), with an mean age of

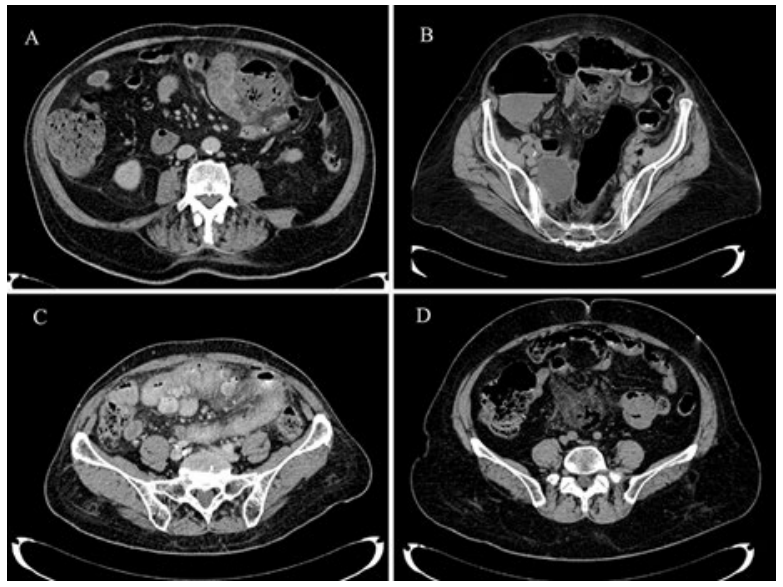

Figure 1. A: jejunal loop thickening with inflammatory changes of the loop and adjacent fat without signs of complication. B: jejunal loop with mesenteric fat trabeculation and pneumoperitoneum isolated bubbles. C: jejunal diverticulum with adjacent fat trabeculation and free fluid. D: diverticulum in the jejuno-ileal junction wall, with mesenteric root inflammation, and gas bubbles contained by adjacent mesenteric fat.

79 years (range: $69-92$ years). Among the comorbidities they presented, one patient on chemotherapy treatment for acute myeloid leukemia, one patient with chronic kidney failure, three patients with dementia and five with arterial hypertension under treatment stand out. Four of our patients had previous abdominal surgeries.

All studied patients had abdominal pain as main complaint, with fever or vomiting, or both, only in four cases (33\%).

Half the patients showed leukocytosis in the laboratory tests practiced at the emergency department, with one case of neutrophilia without leukocytosis.

In six $(50 \%)$ of these patients, data of pneumoperitoneum were found on abdominal $\mathrm{CT}$, while in one case $(8 \%)$, data consistent with intestinal obstruction were observed, and in another case, an abscessed collection was found at admission. The rest of the patients had only inflammation of saccular formations dependent on the jejunum (Fig. 1).

Two patients underwent emergency surgery upon hospital arrival, with intestinal resection of the affected segment (perforated diverticulum prior to intestinal adhesion that caused retrograde obstruction) being carried out in one of them and abdominal cavity lavage and drainage placement using a laparoscopic approach, without intestinal resection, in the other one. Another case was operated after poor evolution with antibiotic treatment, with resection of the compromised area and anastomosis in one surgical time. Pathological anatomy in both cases where bowel resection was practiced revealed data consistent with perforated diverticulosis with diverticulitis and peritonitis. Nine patients (75\%) 
Table 1. Summary of our series results

\begin{tabular}{|c|c|c|c|c|c|c|c|c|}
\hline Gender & Age & $\begin{array}{l}\text { Previous } \\
\text { surgeries }\end{array}$ & $\begin{array}{l}\text { Clinical } \\
\text { findings at } \\
\text { admission }\end{array}$ & CT findings & Treatment & Evolution & $\begin{array}{l}\text { Hospitalization } \\
\text { days }\end{array}$ & Recurrence \\
\hline Male & 88 & Yes & $\begin{array}{l}\text { Abdominal pain } \\
\text { Neutrophilia }\end{array}$ & $\begin{array}{l}\text { Jejunal diverticula } \\
\text { inflammation }\end{array}$ & $\begin{array}{l}\text { Medical } \\
\text { (ertapenem) }\end{array}$ & $\begin{array}{l}\text { Without } \\
\text { complications }\end{array}$ & 3 & No \\
\hline Male & 84 & No & Abdominal pain & $\begin{array}{l}\text { Pneumoperitoneum } \\
\text { with no free fluid }\end{array}$ & $\begin{array}{l}\text { Medical } \\
\text { (ertapenem. ACA) }\end{array}$ & $\begin{array}{l}\text { Without } \\
\text { complications }\end{array}$ & 5 & No \\
\hline Male & 72 & No & $\begin{array}{l}\text { Abdominal pain } \\
\text { Fever } \\
\text { Vomiting } \\
\text { Leukocytosis }\end{array}$ & $\begin{array}{l}\text { Jejunal diverticula } \\
\text { inflammation } \\
\text { Uncomplicated } \\
\text { diverticula in } \\
\text { duodenum and colon }\end{array}$ & $\begin{array}{l}\text { Medical } \\
\text { (meropenem) }\end{array}$ & $\begin{array}{l}\text { Without } \\
\text { complications }\end{array}$ & 9 & No \\
\hline Male & 87 & Yes & $\begin{array}{l}\text { Abdominal pain } \\
\text { Leukocytosis }\end{array}$ & $\begin{array}{l}\text { Jejunal diverticula } \\
\text { inflammation with } \\
\text { associated plastron }\end{array}$ & $\begin{array}{l}\text { Medical } \\
\text { (PTZ, } \\
\text { ertapenem+ciproloxacin) }\end{array}$ & Relapse & 8 & Yes \\
\hline Female & 69 & No & $\begin{array}{l}\text { Abdominal pain } \\
\text { Fever } \\
\text { Leukocytosis }\end{array}$ & $\begin{array}{l}\text { Contained perforation } \\
\text { with mesenteric root } \\
\text { pneumoperitoneum }\end{array}$ & $\begin{array}{l}\text { Medical } \\
\text { (PTZ) }\end{array}$ & $\begin{array}{l}\text { Without } \\
\text { complications }\end{array}$ & 8 & No \\
\hline Female & 76 & No & $\begin{array}{l}\text { Abdominal pain } \\
\text { Leukocytosis }\end{array}$ & $\begin{array}{l}\text { Jejunal diverticula with } \\
\text { wall and mesenteric } \\
\text { inflammation }\end{array}$ & $\begin{array}{l}\text { Surgery (intestinal } \\
\text { resection and } \\
\text { anastomosis) after medical } \\
\text { treatment (PTZ) }\end{array}$ & $\begin{array}{l}\text { Poor evolution } \\
\text { with medical } \\
\text { treatment } \\
\text { Without } \\
\text { postoperative } \\
\text { complications }\end{array}$ & 21 & No \\
\hline Female & 78 & No & $\begin{array}{l}\text { Abdominal pain } \\
\text { Vomiting } \\
\text { Leukocytosis }\end{array}$ & $\begin{array}{l}\text { Jejunal diverticula } \\
\text { inflammation }\end{array}$ & $\begin{array}{l}\text { Percutaneous drainage } \\
\text { (PTZ) }\end{array}$ & Readmission & 60 & Relapse \\
\hline Female & 78 & No & $\begin{array}{l}\text { Abdominal pain } \\
\text { Vomiting } \\
\text { Leukocytosis }\end{array}$ & $\begin{array}{l}\text { Mesenteric } \\
\text { trabeculation and } \\
\text { pneumoperitoneum } \\
\text { isolated bubbles }\end{array}$ & $\begin{array}{l}\text { Medical } \\
\text { (ertapenem) }\end{array}$ & $\begin{array}{l}\text { Without } \\
\text { complications }\end{array}$ & 10 & No \\
\hline Male & 73 & Yes & Abdominal pain & $\begin{array}{l}\text { Jejunal wall thickening, } \\
\text { pneumoperitoneum } \\
\text { Portal pneumatosis }\end{array}$ & $\begin{array}{l}\text { Surgery (cavity lavage and } \\
\text { drainage) } \\
\text { Meropenem, ACA }\end{array}$ & $\begin{array}{l}\text { Wound } \\
\text { infection }\end{array}$ & 8 & No \\
\hline Male & 78 & No & $\begin{array}{l}\text { Abdominal pain } \\
\text { Fever }\end{array}$ & $\begin{array}{l}\text { Jejunal diverticula } \\
\text { inflammation }\end{array}$ & $\begin{array}{l}\text { Medical } \\
\text { (meropenem+voriconazole }\end{array}$ & $\begin{array}{l}\text { Without } \\
\text { complications }\end{array}$ & 10 & No \\
\hline Male & 72 & No & $\begin{array}{l}\text { Abdominal pain } \\
\text { Fever }\end{array}$ & $\begin{array}{l}\text { Jejunal diverticula } \\
\text { inflammation }\end{array}$ & $\begin{array}{l}\text { Medical } \\
\text { (ertapenem) }\end{array}$ & $\begin{array}{l}\text { Without } \\
\text { complications }\end{array}$ & 6 & No \\
\hline Female & 92 & Yes & $\begin{array}{l}\text { Abdominal pain } \\
\text { Vomiting }\end{array}$ & $\begin{array}{l}\text { Signs of intestinal } \\
\text { obstruction } \\
\text { Pneumoperitoneum }\end{array}$ & $\begin{array}{l}\text { Surgery } \\
\text { Resection and anastomosis } \\
\text { Medical (ACA, PTZ) }\end{array}$ & $\begin{array}{l}\text { Without } \\
\text { complications }\end{array}$ & 10 & No \\
\hline
\end{tabular}

ACA: amoxicillin-clavulanic acid, PTZ: piperacillin-tazobactam; CT: computed tomography.

were conservatively treated with antibiotic therapy, with one of them requiring percutaneous drainage for an intraabdominal collection.

Hospitalization period had mean of 13 days, with a range of 3 to 60 days (this longer hospitalization period corresponds to the patient who was operated after conservative management failure). Antibiotic treatment, which was maintained on an outpatient basis in 10 of the 12 cases, lasted a mean of 20 days (range: 10-48).
One of the patients, initially conservatively treated due to CT findings of uncomplicated jejunal diverticulitis, required readmission due to poor evolution at home with oral antibiotic therapy. Upon arrival at the emergency room, the condition had evolved with respect to the moment of discharge, this time presenting with intra-abdominal collection. For its management, intravenous antibiotic therapy and percutaneous drainage of the collection were associated. 
In another patient, late relapse occurred at 2 years, with no complications appearing in neither of both admissions and with resolution of both with intravenous antibiotic therapy.

No mortality associated with this pathology was recorded in our series (Table 1).

\section{Discussion}

Diverticular disease of the small intestine is rare, with an incidence of $0.06-1.5 \%$ (up to $5 \%$ according to series in autopsies) ${ }^{8}$, with the highest incidence being observed at the seventh decade of life and thereafter ${ }^{9}$. However, incidence might be higher, since most patients remain asymptomatic. Diverticula located in the jejunum and ileum are more common in men. They are usually associated with previous existence of intestinal motility disorders due to progressive systemic sclerosis, neuropathies and myopathies, and to the presence of postoperative adherences that cause sub-occlusive recurrent conditions ${ }^{10}$. In most cases, there are no complications, but it can be a cause of acute abdomen.

Clinical presentation can be highly unspecific, with diffuse abdominal pain, intestinal malabsorption with diarrhea and weight loss, low digestive hemorrhage, fever, and even acute abdomen in case of inflammation with or without diverticulum perforation ${ }^{11,12}$.

In cases of complication and acute clinical presentation with pain, fever, intestinal obstruction, hematochezia, weight loss or other symptoms, the tests to be performed are abdominal CT with intravenous contrast, magnetic resonance imaging or endoscopy ${ }^{13-15}$, or both. Sometimes, complementary tests are not enough to reach a safe diagnosis, and surgical exploration becomes necessary (laparotomy or laparoscopy).

The complications that can appear include inflammation, bleeding, obstruction, abscess formation and perforation of one or several diverticula ${ }^{16}$. Their management can be conservative, with resuscitation maneuvers in case of bleeding and intravenous antibiotic therapy when inflammation or abscess occur ${ }^{17,18}$. In case of not responding to these measures, more aggressive maneuvers are required, percutaneous drainage or laparoscopy/exploratory laparotomy for intestinal resection of the compromised segment, usually followed by primary anastomosis ${ }^{19-21}$.

\section{Acknowledgements}

Special thanks to doctors Javier López Monclús and José Luis Lucena de la Poza for their help in encouraging and improving the article.

\section{Conflicts of interest}

The authors declare not having any conflicts of interest.

\section{References}

1. Akhrass R, Yaffe MB, Fischer C, Ponsky J, Shuck JM. Small-bowel diverticulosis: perceptions and reality. J Am Coll Surg. 1997;184:383-8.

2. Makris K, Tsiotos GG, Stafyla V, Sakorafas GH. Small intestinal nonmeckelian diverticulosis: clinical review. J Clin Gastroenterol. 2009;43:201-7.

3. Chow DC, Babain M, Taubin HL. Jejunoileal diverticula. Gastroenterologist. 1997; 5:78-84

4. Kouraklis G, Mantas D, Glivanou A, Kouskos E, Raftopoulos J, Karatzas G. Diverticular disease of the small bowel: report of 27 cases. Int Surg.2001;86:235-9.

5. Doland JW. Major complications of small bowel diverticula. Ann Surg. 1979;190:183-88.

6. Kassir R, Boueil-Bourlier A, Baccot S. Jejuno-ileal diverticulitis: etiopathogenicity, diagnosis and management. Int J Surg Case Rep. 2015;10:151-3.

7. Singal R, Gupta S, Airon A. Giant and multiple jejunal diverticula presenting as peritonitis a significant challenging disorder. J Med Life. 2012;15:308-10.

8. Miller RE, McCabe RE, Salomon PF, Knox WG. Surgical complications of small bowel diverticula exclusive of Meckel's. Ann Surg. 1970;171:202-10.

9. De Bree E, Grammatikakis J, Christodoulakis M, Tsiftsis D. The clinical significance of acquired jejunoileal diverticula. Am J Gastroenterol. 1998; 93:2523-8.

10. Krishnamurthy S, Kelly MM, Rohrmann CA, Schuffler MD. Jejunal diverticulosis. A heterogeneous disorder caused by a variety of abnormalities of smooth muscle or myenteric plexus. Gastroenterology. 1983;85:538-47.

11. Kassir R, Boueil-Bourlier A, Baccot S. Jejuno-ileal diverticulitis: etiopathogenicity, diagnosis and management. Int J Surg Case Rep. 2015;10:151-3.

12. Parlakgumus A, Ezer A, Tarim A. A rare cause of gastrointestinal bleeding: jejunal diverticulosis. J Coll Physicians Surg Pak. 2016;26:870-1.

13. Coulier B, Maldague $P$, Bourgeois A, Broze B. Diverticula of the small bowel: CT diagnosis. Abdom Imaging. 2007;32:228-33.

14. Macari $M$, Faust $M$, Liang $H$, Pachter $H L$. CT of jejunal diverticulitis: imaging findings, differential diagnosis and clinical management. Clin Radiol. 2007;62:737.

15. Blam ME, Metz DC. Image of the month. A wind sock web deformity of the proximal duodenum. Gastroenterology. 2000;119:292.

16. Ross CB, Richards WO, Sharp KW, Bertram PD, Schaper PW. Diverticular disease of the jejunum and its complications. Am Surg. 1990;56:319-24.

17. Horesh N, Klang E, Gravetz A, Nevo Y, Amiel I, Amitai MM, et al. Jejunal diverticulitis. J Laparoendosc Adv Surg Tech A. 2016;26:596-9.

18. Novak JS, Tobias J, Barkin JS. Nonsurgical management of acute jejunal diverticulitis: a review. Am J Gastroenterol. 1997;92:1929-31.

19. Laiz Díez B, González González J, Ruiz-Tovar J, López Monclús J, Durán Poveda M. Jejunal pseudodiverticulosis. Three cases report. Rev Esp Enferm Dig. 2017;109:305-6.

20. Spasojevic M, Naesgaard JM, Ignjatovic D. Perforated midgut diverticulitis: revisited. World J Gastroenterol. 2012;18:4714-20.

21. Chendrasekhar A, Timberlake GA. Perforated jejunal diverticula: analysis of reported cases. Am Surg. 1995;61:984-8. 